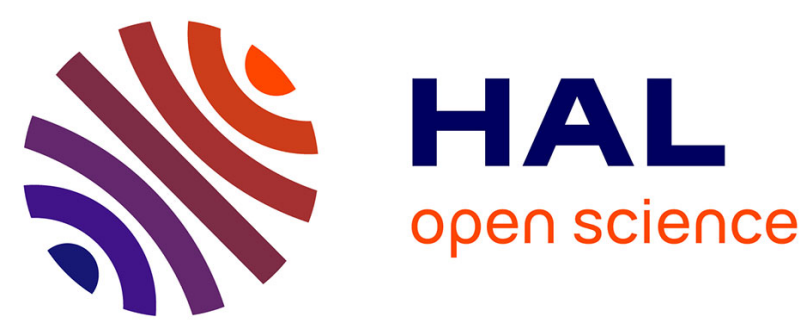

\title{
A Systematic Mapping of Game-Based Methods to Tackle a Public Health Problem
}

\author{
Tiago Lima, Clodoveu Augusto Davis
}

\section{To cite this version:}

Tiago Lima, Clodoveu Augusto Davis. A Systematic Mapping of Game-Based Methods to Tackle a Public Health Problem. Esteban Clua; Licinio Roque; Artur Lugmayr; Pauliina Tuomi. 17th International Conference on Entertainment Computing (ICEC), Sep 2018, Poznan, Poland. Springer International Publishing, Lecture Notes in Computer Science, LNCS-11112, pp.317-323, 2018, Entertainment Computing - ICEC 2018. 10.1007/978-3-319-99426-0_37 . hal-02128583

\section{HAL Id: hal-02128583 \\ https://hal.inria.fr/hal-02128583}

Submitted on 14 May 2019

HAL is a multi-disciplinary open access archive for the deposit and dissemination of scientific research documents, whether they are published or not. The documents may come from teaching and research institutions in France or abroad, or from public or private research centers.
L'archive ouverte pluridisciplinaire HAL, est destinée au dépôt et à la diffusion de documents scientifiques de niveau recherche, publiés ou non, émanant des établissements d'enseignement et de recherche français ou étrangers, des laboratoires publics ou privés. 


\title{
A systematic mapping of game-based methods to tackle a public health problem ${ }^{\star}$
}

\author{
Tiago França Melo Lima ${ }^{1,2[0000-0003-1319-8530]}$ and Clodoveu Augusto Davis \\ Jr. ${ }^{2[0000-0002-7327-848 X]}$ \\ 1 Federal University of Ouro Preto (UFOP), João Monlevade - MG, Brazil. \\ ${ }^{2}$ Federal University of Minas Gerais, Belo Horizonte - MG, Brazil. \\ tiagolima@decsi.ufop.br, clodoveu@dcc.ufmg.br
}

\begin{abstract}
Mosquito-borne diseases, such as dengue, endanger about half of the world's population. Their spread is affected by individual behavior in our mostly urban society. Public health policies generally include awareness campaigns on the control of the vectors. While gamebased initiatives are developed and used to train students and professionals, support patients and educate citizens, public health education remains neglected. In this study, we identify game-based approaches to support education about diseases transmitted by Aedes mosquitoes. We carried out a systematic mapping to identify studies which address a proposal, use or contain an evaluation of game-based methods, aiming to raise awareness and promote behavior changes regarding dengue and its prevention. Only 12 papers met the criteria for inclusion and exclusion, and those were selected and categorized. As part of an ongoing project, next steps include adding other databases and other mosquito-borne diseases (e.g., malaria) and drafting guidelines to support the design of games for public health education about mosquito-borne diseases.
\end{abstract}

Keywords: Systematic mapping $\cdot$ Serious games $\cdot$ Gamification $\cdot$ Public health · Education · Awareness · Aedes aegypti - Dengue.

\section{Introduction}

A global public health concern, dengue is a mosquito-borne viral disease. Estimates suggest that about 3.9 billion people are at risk [1]. Its primary vector is the Aedes aegypti mosquito, which also transmits chikungunya, yellow fever and zika viruses. Vector population control is an important strategy to face this problem. Humans behavior may contribute to the growth of vector population $[22,23]$, for instance, through the improperly stock of water and inappropriate disposal of solid waste which can become vector breeding sites. Thereby, citizens have an important role and must be included in public health policies.

Generally, population awareness is based on traditional media advertisement and educational campaigns (e.g., classes, talks, theater) in schools and public

\footnotetext{
* The authors acknowledge the support from CNPq and FAPEMIG, Brazilian agencies
} in charge of fostering research and development, and IFIP Digital Equity Committee. 
places $[4,5,9,17,19]$. Game-based approaches are powerful tools to support education, awareness, engagement and behavior changes [2,6,7,20,26,27]. In this context, serious games and gamification can be used to enhance the outcomes of education-based policies for public health. An example is a game which tackles on two related neglected and emerging tropical infectious diseases - Visceral Leishmaniasis and American Cutaneous Leishmaniasis [18].

In this study, we present an overview of game-based methods applied in education about dengue and other diseases transmitted by Aedes mosquito.

\section{The systematic mapping process}

There are some differences between Systematic Mapping (SM) and Systematic Literature Review (SLR) studies. The first may be used as a previous step toward the latter, as it can help to identify areas where is more appropriate to conduct an SLR or a primary study [10,24]. In this study, a systematic mapping was performed. As described by [24], the process steps include: (i) definition of research questions, (ii) conduct search for primary studies (all papers), (iii) screening of papers for inclusion and exclusion (relevant papers), (iv) keywording of abstracts, and (v) data extraction and mapping of studies.

The goal of this study is to identify and analyze game-related methods aiming to understand their application in the context of public health education, in particular, those designed to support awareness and behavior changes for dengue prevention. For such, we established the following research questions:

- RQ1: Which game-based methods were used to raise awareness about Aedes mosquito-borne diseases and how to prevent them?

- RQ2: Which types of games have been proposed or used?

- RQ3: In which context and educational levels were they investigated?

The search query used was: (game OR gamification) AND (dengue OR zika OR chikungunya OR "yellow fever" OR Aedes OR mosquito). The electronic databases searched were: ACM Digital Library, IEEE Xplore, PubMed, ScienceDirect, Scopus, Springer Link. The results covered articles, conference papers and book chapters published and indexed until May 10, 2018 (Table 1). Although some databases returned a large number of results, the vast majority of them had no relation to the research objectives. For instance, many papers had as subject the 2014 Olympic Games in Brazil and zika epidemic. Furthermore, there are a reasonable number of apps and games related to the subject available on the web and in app stores. However, the results covered only seven different games (see Table 2). Details about the research such as inclusion/exclusion criteria and protocol are available at www.github.com/ufopleds/publichealthgames.

\section{Results and discussion}

Few studies addressed games-based methods aimed at public health education about diseases transmitted by Aedes. In this section, we present some information about them, such as how they were conducted and which were their findings. 
Table 1. Results summary

\begin{tabular}{|l|l|l|l|l|l|l|}
\hline & ACM & IEEE & PubMed & ScienceDirect & Scopus & Springer \\
\hline \# papers & 3 & 5 & 88 & 1464 & 143 & 3877 \\
1st selection & 3 & 3 & 4 & 7 & 19 & 4 \\
2nd selection (relevant papers) & 1 & 3 & 1 & 1 & 10 & 3 \\
\hline Total after removing duplicates & \multicolumn{7}{|c|}{12} & \\
\hline
\end{tabular}

Table 2. List of publications grouped by type

\begin{tabular}{|l|l|}
\hline Type & References \\
\hline journal & {$[3],[11],[12],[13],[14],[29]$} \\
conference & {$[8],[15],[25],[28]$} \\
book chapter & {$[16],[21]$} \\
\hline
\end{tabular}

Regarding the game-related methods used, RQ1, (Table 3), three of the studies addressed the game design by volunteer participants. Both the design of a game (made by authors) and the evaluation of a game were approached by four studies. Two of them used gamification. None of the studies presented a game from its conception, design and development phases to its systematic evaluation.

Table 3. Game related-methods

\begin{tabular}{|l|l|}
\hline Game-related methods & References \\
\hline Game design (by participants) & {$[11,13,16]$} \\
Game design and development (by authors) & {$[15,21,25,28]$} \\
Gamification & {$[15,21]$} \\
Game evaluation & {$[3,12,14,29]$} \\
\hline
\end{tabular}

Answering RQ2, both digital and analog games were covered (see Table 4). However, the number of different games is even lower, and it is worse if we consider their availability to be used by educators and public health agents. There are two board games - here, the difficulty is having physical access to them. For computers, there are two options, but we found just one available online with the installer - Pueblo Pitanga: enemigos silenciosos ${ }^{3}$. Similarly, from the three games for mobile devices, we found only one publicly available $-\mathrm{X}$-Dengue ${ }^{4}$. The context and educational level (RQ3) varies according to the study.

Two of the papers reported a study in which authors investigated the ability of a child to create educational games related to dengue using drawings $[11,13]$. An active role in the creation process was also the subject of another study, in which was used a participatory design to engage a community and students to devise mobile apps.

\footnotetext{
${ }^{3}$ http://www.pueblopitanga.com

${ }^{4}$ https://play.google.com/store/apps/details?id=com.leds.xdengue
} 
Table 4. Summary of games

\begin{tabular}{|l|l|l|l|}
\hline Game & Platform & References & Easily acessible \\
\hline Jugando en salud: dengue & board & {$[29]$} & no \\
Good-bye to dengue & board & {$[12,14]$} & no \\
Pueblo Pitanga: enemigos silenciosos & computer & {$[8]$} & yes \\
Sherlock Dengue 8 & computer & {$[3]$} & no \\
Hugo against dengue & mobile & {$[25]$} & no \\
X-Dengue & mobile & {$[15]$} & yes \\
AedesBusters & mobile & {$[21]$} & no \\
\hline
\end{tabular}

The board games were the subject of three studies. The game Jugando en salud: dengue was evaluated using a pre- and post-test experimental design with 621 students between eight to sixteen-years-old from nine different schools of a Venezuelan city [29]. According to authors, the game had a good acceptance and contributed to improving knowledge about dengue and its prevention. The game Good-bye to dengue was used in two studies. In one, the authors conducted a postgame debriefing with 81 Filipino students to explore aspects such as students' feelings, perceptions and information learned [12]. In the other, they evaluated the effectiveness of the game to increase knowledge, positive attitudesbeliefs, and self-efficacy for dengue prevention using an experimental design (preand post test) with primary and secondary students from Philippine schools [14].

Design, development and evaluation of digital games were the subjects of the other studies. [25] presented a prototype of a mobile game (Hugo against dengue). A simulation game that uses a view from the perspective of a mosquito was described by [28]. The game Pueblo Pitanga: Enemigos Silenciosos had its design patterns analyzed by [8]. The design of a mixed-reality game (2D, augmented reality and virtual reality), $X$-Dengue, was presented by [15]. The game Sherlock Dengue 8 was used in a study-case addressing guidelines for designing and use collaborative-competitive serious games[3]. Moreover, a mobile app used gamification aiming to incentive volunteer contributions of Aedes aegypti breeding sites. Although such studies have in some way presented aspects about game design, development and evaluation, they lack a deeper and systematic evaluation to demonstrate their advantages and limitations to support awareness and behavior change so they can be used as tools for public health policies.

More than half of the worlds population live in areas where Aedes species are present. There is a consensus about habits to prevent vector breeding sites inside houses, and in many countries, this information is widely disseminated using traditional media and campaigns. However, the exclusive use of these methods demonstrated to be ineffective, since most of vector breeding sites are located inside or around houses. Innovative approaches such as those based on games are needed. Although, there is a lack of games and studies addressing public health education such as mosquito-borne diseases. Primary studies should be systematically undertaken to design and evaluate game-based methods and tools, which could be easily scalable if they prove to be effective and efficient to achieve awareness and behavioral changes. 


\section{Final remarks}

Games for health is an emergent research area. There are many efforts aimed at training health students and professionals and rehabilitation of patients. However, there is a significant shortage of initiatives addressing global public health problems such as mosquito-borne diseases.

In this study, we performed a systematic mapping of game-based methods aiming to aware and promote behavior changes regarding dengue and its prevention. While some research areas (e.g., software engineering education) have a significant number of studies on games application, we found few studies related to public health education on diseases transmitted by Aedes, and fewer were those that did a systematic evaluation of the outcomes. The costs of mosquitoborne diseases are very high, and a significant amount of resources is used to promote awareness, but using advertisement in traditional media. Part of these should be used to conduct scientific research aiming to develop and evaluate the application of game-based methods to tackle public health complex problems, such as mosquito-borne diseases. The outcomes could be replicated and scalable.

As part of an ongoing project, future works include (i) adding other databases and games designed to target other mosquito-borne diseases (e.g., malaria), (ii) elaborate guidelines to support the design of games to promote public health education about mosquito-borne diseases.

\section{References}

1. Bhatt, S., Gething, P.W., Brady, O.J., Messina, J.P., Farlow, A.W., Moyes, C.L., Drake, J.M., Brownstein, J.S., Hoen, A.G., Sankoh, O., et al.: The global distribution and burden of dengue. Nature 496(7446), 504-507 (2013)

2. Boyle, E.A., Connolly, T.M., Hainey, T., Boyle, J.M.: Engagement in digital entertainment games: A systematic review. Computers in Human Behavior 28(3), 771-780 (2012)

3. Buchinger, D., Hounsell, M.d.S.: Guidelines for designing and using collaborativecompetitive serious games. Computers \& Education 118, 133-149 (2018)

4. Chinnakali, P., Gurnani, N., Upadhyay, R.P., Parmar, K., Suri, T.M., Yadav, K., et al.: High level of awareness but poor practices regarding dengue fever control: a cross-sectional study from North India. North American Journal of Medical Sciences 4(6), 278 (2012)

5. Claro, L., Barreto, L., Kawa, H., Tricai Cavalini, L., Garcia Rosa, M.L.: Community Participation in Dengue Control in Brazil. Dengue Bulletin 30 (2006)

6. Connolly, T.M., Boyle, E.A., MacArthur, E., Hainey, T., Boyle, J.M.: A systematic literature review of empirical evidence on computer games and serious games. Computers \& Education 59(2), 661-686 (2012)

7. Dondlinger, M.J.: Educational video game design: A review of the literature. Journal of Applied Educational Technology 4(1), 21-31 (2007)

8. Elizondo, E.R.: Identification of design patterns for serious games in an educational videogame designed to create awareness on dengue and malaria fever. In: IFIP World Information Technology Forum. pp. 85-95. Springer (2016)

9. Khun, S., Manderson, L.: Community and school-based health education for dengue control in rural Cambodia: a process evaluation. PLoS Negl Trop Dis 1(3) (2007) 
10. Kitchenham, B., Charters, S.: Guidelines for performing systematic literature reviews in Software Engineering. Tech. rep., Keele Univ. and Durham Univ. (2007)

11. Lennon, J.L., Coombs, D.W.: Study of child-invented health educational games on dengue fever. Dengue Bulletin 26, 195-202 (2002)

12. Lennon, J.L., Coombs, D.W.: The Good-bye to Dengue game: Debriefing study. Simulation \& Gaming 36(4), 499-517 (2005)

13. Lennon, J.L., Coombs, D.W.: Child-invented health education games: A case study for dengue fever. Simulation \& Gaming 37(1), 88-97 (2006)

14. Lennon, J.L., Coombs, D.W.: The utility of a board game for dengue haemorrhagic fever health education. Health Education 107(3), 290-306 (2007)

15. Lima, T., Barbosa, B., Niquini, C., Araújo, C., Lana, R.: Playing against dengue - Design and development of a serious game to help tackling dengue. In: 5th Int. Conf. on Serious Games and Applications for Health. pp. 1-8. IEEE (2017)

16. Lucena, T.F.R., Velho, A.P.M., Dorne, V.D., Domingues, D.M.G.: Devising mobile apps: participatory design for endemic diseases transmitted by the mosquito Aedes. In: Mobile Story Making in an Age of Smartphones, pp. 139-150. Springer (2018)

17. Luna, J., Chain, I., Hernandez, J., Clark, G., Bueno, A., Escalante, R., Angarita, S., Martinez, A.: Social mobilization using strategies of education and communication to prevent dengue fever in Bucaramanga, Colombia. Dengue Bulletin (2004)

18. Luz, S., Masoodian, M., Cesario, R.R., Cesario, M.: Using a serious game to promote community-based awareness and prevention of neglected tropical diseases. Entertainment Computing 15, 43-55 (2016)

19. Madeira, N.G., Macharelli, C.A., Pedras, J.F., Delfino, M.C.: Education in primary school as a strategy to control dengue. Revista da Sociedade Brasileira de Medicina Tropical 35(3), 221-226 (2002)

20. Michael, D.R., Chen, S.L.: Serious games: Games that educate, train, and inform. Muska \& Lipman/Premier-Trade (2005)

21. Moura, J.A.B., de Barros, M.A., Oliveira, R.P.: Marketplace-Driven, GameChanging IT Games to Address Complex, Costly Community Problems. In: Digital Marketplaces Unleashed, pp. 193-204. Springer (2018)

22. Padmanabha, H., Soto, E., Mosquera, M., Lord, C., Lounibos, L.: Ecological links between water storage behaviors and Aedes aegypti production: implications for dengue vector control in variable climates. Ecohealth 7(1), 78-90 (2010)

23. Pai, H.H., Yu-Jue, H., Hsu, E.L.: Impact of a short-term community-based cleanliness campaign on the sources of dengue vectors: an entomological and human behavior study. Journal of Environmental Health 68(6), 35 (2006)

24. Petersen, K., Feldt, R., Mujtaba, S., Mattsson, M.: Systematic mapping studies in software engineering. In: EASE. vol. 8, pp. 68-77 (2008)

25. Porcino, T.M., Strauss, E., Clua, E.G.: Hugo against dengue: a serious game to educate people about dengue fever prevention. In: 3rd International Conference on Serious Games and Applications for Health. pp. 1-5. IEEE (2014)

26. Prensky, M.: Don't bother me, Mom, I'm learning! Paragon House (2006)

27. Squire, K.: Video games in education. Int. J. Intell. Games \& Simulation 2(1), 49-62 (2003)

28. Stifter, C., Edenhofer, S., von Mammen, S.: Come Fly with me - Perceive the world through a mosquito's senses. In: 8th Int. Conf. on Games and Virtual Worlds for Serious Applications. pp. 1-4. IEEE (2016)

29. Vivas, E., Guevara de Sequeda, M.: Un juego como estrategia educativa para el control de Aedes aegypti en escolares venezolanos. Revista Panamericana de Salud Pública 14, 394-401 (2003) 